\title{
State Policy of Primary and Secondary Education of the Republic of India in Relation to the Poorest Strata of Society in 1992-2002
}

\author{
Marat Z. Galiullin ${ }^{1}$ \\ ${ }^{1}$ Kazan (Volga Region) Federal University, Kazan, Russia \\ Correspondence: Marat Z. Galiullin, Kazan (Volga Region) Federal University, 420008, Kazan, Kremlyovskaya \\ Street 18, Russia. E-mail: maratscorpion@yandex.com
}

Received: June 2, 2015 Accepted: June 15, 2015 Online Published: June 29, 2015

doi:10.5539/jsd.v8n5p169

URL: http://dx.doi.org/10.5539/jsd.v8n5p169

\begin{abstract}
The importance of the problem is determined by the fact that since the time India had got its independence the problem of poverty in the country remains to be a matter of serious concern. Social inequality in the researched country in a certain way affects its system of education. Therefore, the main aim of this article is to describe the state policy of primary and secondary education of the Republic of India in relation to the poorest segments of society at the turn of XX-XXI centuries and to identify its main results. The leading method of the study of this problem is the historical-comparative. This method allows to compare the data of governmental programs in primary and secondary education among the poorest segments of the population on the basis of historical sources and identify the dynamics of growth or decline of literacy among the Indian population. The article presents the results suggestive of the effect of economic, cultural and mental processes which took place in the Republic of India at the turn of XX-XXI centuries on the level of accessibility of public education and literacy of the Indians. Moreover, particular features of the most important national programs in the sphere of primary and secondary education were disclosed in the 8th and 9th Five Year Plans. The content of this article may be useful for the study of the institutional history of education as well as for contemporary public debate on the role and effectiveness of governmental programs in primary and secondary education.
\end{abstract}

Keywords: the National Policy of Education, the Program of Action, the poorest strata, registered castes and tribes

\section{Introduction}

\subsection{Background}

The Republic of India is anticipating bright future. The country is going to space exploration by leaps and bounds, making great strides in information and computer fields. Nowadays India is in the forefront of the development of economy and modern electronic technology, in the first flight in terms of GDP growth and in the sphere of the software. However India is not able to solve its main problem- poverty. This problem is not only the destiny of India. There are hundreds of countries in the world having similar problems. It concerns almost the whole of Africa, the biggest part of South East Asia, a lot of countries in Europe and America (Volodin \& Shirokov, 2002). This issue is nowhere being raised as sharply as it is in the Republic of India because none of these countries demonstrate such a rapid growth of the economy (India: strana i eyo regiony, 2000).

The only state that can be compared to the growth rates and the number of people is the People's Republic of China. But there are no such acute problems of poverty, insecurity and illiteracy of the majority of the population (Doklad o chelovecheskom razvitii, 2011). Problems of food security and poverty were partially resolved in China in the late 80s. The problem of accessibility of education in China is not completely solved, but it is not as vital as it is in India. India should resolve the problem in the nearest future, if the country has an intention to become a highly developed and respected state.

\subsection{Status of a Problem}

The Russian Indology does not pay enough attention to the problems of the institutional history of the primary and secondary education but increasingly deals with them in the context of social policy (Bragina 2002; Kruglova 2008; Malyarov 2006).

Another aspect of the problem of primary and secondary education requires consideration of national, religious 
and mental characteristics of the local population, which essentially discordant with the traditional concepts of classical education in the European understanding (Religiya i sekulyarism na Vostoke 1993; Suprunova, 2009).

\subsection{The Research Hypothesis}

Nowadays problems of poverty, accessibility to education, humanitarian and food security come to the fore for modern researchers connected with the greater increase of the number of inhabitants on the planet. And the solution of these problems requires urgent actions, because future of the world depends on it.

The author's hypothesis is that poverty and the situation in which people are forced to live with a burning desire to survive has led people to doing some incredible things to stay alive. Children are taken out of school at a very young age and sent to work to feed their families. Many of them never attended the classes at all. Most parents of the lower castes consider education as a privilege of higher castes and the rich.

\section{Methodological Framework}

\subsection{Research Methods}

The research is based on the following principles: a) scientific method - drawing conclusions based on the analysis of the full range of documents and scientific literature and taking into account all the events and phenomena; b) impartiality - characteristics of the studied events and phenomena of the historical process, the views of the leaders without any preference from the side of the researcher; c) consistency - taking into account the diversity of factors affecting the historical process as the objective and subjective, internal and external, local as well as global; d) historicism - consideration of historical processes and phenomena in their continuous development and transformation.

The presentation of materials has been built in subjective - chronological order. The research requires integrated approach to the development of the basic material on the issue.

The usage of comparative-historical method helped to realize how reforms in education at certain stages of political development of India were demanded.

Historical-genetic method used in the work made it possible to identify the general course of the events. This method enabled to highlight causal relationships between the major economic and social problems of the Republic of India.

The concrete historical analysis allowed to consider the events and phenomena in the context of the era when the assessment of events is given from the perspective of a particular historical situation. This method is comprehensively applicable to study the history of India during the leadership of the Bharatiya Jana Parti because events and phenomena were considered in close connection with their historical necessity and significance.

Historical- systematic method was used in the research. The systemic nature of social and historical development means that all the events, situations and processes of this development have causal links and are connected functionally. This approach is applicable to the study of historical processes related to the preparation of students in primary and secondary classes and their social adaptation in the Republic of India.

\subsection{Eighth Five-Year Plan (1992-1997)}

The development of the public education system in the Republic of India according to governmental plans was started in 1951, the time of commencement of the First Five-Year Plan. Since that time the set of problems related to the issues of education has become an integral part of any new plan for the next economic and social development of the country. Primary, higher and technical education remains to be the main priorities of state planning in all the years of independence. With the emergence of more specialized problems of education they were reflected in the development strategy: first the problem of the elimination of illiteracy among the adult population of the country and the implementation of universal compulsory primary education was distinguished in the sixth five-year plan (1980-1985). In the eighth five-year plan the main emphasis was made on the development of women's education and food support for primary school students.

1986 became a turning point in state policy in the field of education. This year the Indian Parliament approved the program "National Policy of Education" (NPE), and adopted "the Program of Action" (PoA) which were necessary for its implementation. Before the adoption of the NPE state policy had had regular planned features without addressable target orientation, reflecting the idea of fairly uniform expansion of educational opportunities across regions and social groups with the growth of public spending. A new state approach was intended to eliminate the formed disparities in levels of education between men and women, adults and children, between primary and secondary, humanities and technical education, literacy levels in different states, in cities 
and villages, to prevent a huge dropout rate of student at various levels of education. The years that have passed since the adoption of the NPE were a time of rapid "development" of addressable and objective, national and state education programs.

According to the PoA, the realization of the most difficult tasks of education should take place in stages. For example, the achievement of universal and compulsory primary education in the country (up to and including Grade 8) at the first stage (the end of the 9th Five-Year Plan) should spread to the 5th grade or the first stage of primary school. The most important direction of PoA became mobilization of public support to improve the school education. The 73rd and 74th amendments to the Constitution of the Republic require that all local governments (panchayats) should be responsible for conditions of education at schools at local administration level (Constitution of India, 2012).

One of the first governmental programs that has appeared since the adoption of NPE, was a program of "Blackboard Operation", the first phase of which took place in the sixth and seventh five-year plans of NPE. It was created to solve the acute problem of school buildings, lack of furniture, blackboards, libraries, laboratories, textbooks, teacher shortages. In the first phase it was supposed to provide all primary schools with two teachers and teaching materials completely at the expense of the central government and school facilities at the expense of state budgets. In the second stage it was supposed to increase the number of teachers up to 3 people per school. From $1987 / 88$ to $1999 / 2000$ books were received by 523 thousand elementary schools of the first stage and 127.3 thousand schools of the second stage. The third teacher appeared in 83 thousand primary schools of the first stage in 75 thousand schools of the second stage.

In 1984/85 the pilot project "Computer literacy in schools" was started in collaboration with the Ministry of Electronics. From 1992-93 it became the state program for the whole country. During the period of the 8th Five-Year Plan computers were installed in 2371 schools. From the 1st of April 1999 the program has ceased to exist but at the initiative of the Ministry of electronics improved program for the dissemination of computer literacy came into force during the Eleventh Five-Year (2008-2012). In 1993 at the initiative of the Planning Commission the program "Strengthening of vocational guidance in secondary schools" was developed. Though this program is not widespread (the central government has transferred funding to the states), still most of the states have shown great interest in it. So, in Indore (Madhya Pradesh), Visakhapatnam (Andhra Pradesh) and Ludhiana (Punjab) training courses of ready-made clothes making were opened for secondary schools. The aim of the program also includes the search for the most talented students and their preparation for taking part in the international competitions (Sauvant \& Pradhan, 2009).

\subsection{Ninth Five-Year Plan (1998-2002)}

In the ninth five-year plan the government pays attention to the early childhood education (responsibility for it lies on the local, urban and rural governments) in order to make it a necessary step for the universalization of the primary education in the country as well as the all-round development of the primary education (India segodnya, 2005).

NPE considers that the core of curricula should be strengthening of the national cultural component. On the one hand, the program "Support for teaching of cultural subjects and national values" implies an increase in the programs of the number of cultural disciplines, on the other hand - the organization of training courses of music, dancing and some handicrafts. This is a modern program, which continues to operate today. The first public investment in it was made in 1999/2000.

Particular attention in NPE is given to the teachers training as a necessary condition to improve the quality of education. In 1987/88 the governmental program "Restructuring and reorganization of teacher training" started to operate. According to it every district must have a local "Institute of teacher training" for primary schools and system of alternative, non-formal education and schools for adults. It also reflects problems of teachers staff for secondary schools. It has raised the status of educational institutions which were training staff for secondary schools to college level (initial stage of higher education). By 19991 million 200 thousand teachers have been trained within this program. In addition to training teachers received the necessary information of the usage of tools and equipment provided for schools within the program "Blackboard".

To achieve universal literacy, first of all the problems of primary education must be solved. According to the Constitution of the Republic of India (The Constitution of India, 1990), it was given 10 years for it. By 1960 it was assumed that India would be a country where all children at age 6-14 years would have the primary education (Gupta \& Sarkar, 1982). But 50 years later the problem has not been resolved, even despite the progress made in the $1990 \mathrm{~s}$. The primary education is one of the priorities of the state policy: according to the 9th five-year plan $58 \%$ of all public investment was allocated education. This is the highest percentage in the 
history of the five-year plans. The most extensive and well-funded programs were aimed at improving of younger pupils training. The 83rd Amendment to the Constitution was taken for consideration of the Parliament. It declared the right for compulsory and free education for children of 6-14 years as their fundamental right. On the recommendation of the National Committee of Ministers of Education of the state the public program "Universal campaign for education" was declared (Sarva, 2010). According to this program, by 2003 absolutely all children of 6-14 years must attend some school; all children of appropriate age should have complete five year education by 2007, complete the eight-year education - by 2010 .

\subsection{Food Support for Primary Education}

One of the main programs for elementary education in 1994 was the "Program for elementary education among districts". Its goals are to decline a dropout rate to $10 \%$; increase an educational progress to $25 \%$; reduce the gap in the number of school boys and girls up to $5 \%$. The basic territorial unit for the program is a county, where planning, financing, monitoring involving local authorities are carried out. The central government covers $85 \%$ of the cost of the program, $15 \%$ is funded by the state governments. First of all the counties with overall low literacy or low female literacy are chosen. In 1994 the program was over-acted in 42 districts, in 2000 - in 215 districts of 15 states, in 2010 - in 417 districts of 26 states (Malyarov, 2010).

The state program "Food support for primary education", or as it is more commonly titled "Mid-day breakfast" (translated from English Mid-day Meals Scheme) became extremely important, especially in rural areas. It has been working since the 15 August 1995. To increase school attendance of the most young contingent of pupils (6-11 years, 1-5 grades), during school hours they are fed by breakfasts prepared in school kitchen. For many children from the poorest families it is the only one guaranteed meal a day. This is one of the most expensive programs of the central government, since it is necessary to provide not only food for free, but also the construction of the kitchen, and cook services. In 1999-2000 more than 99 million pupils from 688 thousand elementary schools were provided with hot meals during a school time.

\subsection{Programs to Eliminate Gender Inequalities and Help People with Disabilities}

According to all socio-economic indicators women seriously lagged behind men. Especially difficult was the situation with rural women (the rural population in 1971 was 80,1\%) (India, 1994). The government of India was strongly convinced to end traditional discrimination against women in the education field.

It was started in 1989 by the program "Reservation for women» (Empowering Education, 2012). It was deployed in rural schools in 51 villages in 7335 districts of 8 states. The program "Building guesthouses and dormitories for schoolgirls," concerns only female representatives, and it is aimed at expanding opportunities to get adolescent girls education in secondary school (literally, Empowering Education). In addition to primary education, active state policy also spreads to a number of targeted niche in the educational system of the Republic of India. After the adoption in 1995 of the law on equal rights for people with physical or mental illnesses, a government program "Integrated education of children with disabilities" appeared. This program runs at $100 \%$ central cost coverage in 27 states and 5 union territories in 22 thousand schools for more than 95 thousand sick children under the age of 18 years.

The direction of state policy of women education to make them equal with the rest of society gained exceptional value in the 1990s.

\subsection{The Elimination of Illiteracy among the Adult Population}

Such a huge scale and complex problem as the elimination of adult illiteracy requires state intervention. There has been functioning "The national mission to raise literacy" since 1988. It is aimed at teaching the basic elements of literacy of more than 100 million people aged 13-35 years, including adolescents 9-14 years old, who are not comprised by the formal education system.

The dominant directions are to attract volunteers for adult teaching; to take into account local conditions; to create conditions for self-education of adults completing their full-time study. It is supposed to deploy a network of rural libraries for it. At the courses for adults in addition to general subjects the foundations of legal and economic knowledge and the basics of ecology are taught. The program was launched in 556 districts. Over $60 \%$ of trainees are adult women; $22 \%$ - representatives of registered castes, $13 \%$ - the registered tribes. During the 9th five-year period plan primary aims of the program became four northern states - Bihar, Madhya Pradesh, Uttar Pradesh, Rajasthan - where the main core of illiteracy in the country is concentrated.

\section{Results}

The special direction of the state policy is the creation of conditions for education of people belonging to the 
registered by castes tribes. Their right to the state custody, including education, is enshrined in the Constitution: "The state will stand guard over the economic interests, and promote the education of the backward sections of society, particularly the registered casts and tribes". In order to implement this thesis, the country has introduced the practice of reserving a certain percentage of seats for representatives of these strata in the elected bodies, public service and educational institutions. In accordance with the law of reservation the administration of each state determines (defines) the quota itself, which is allocated for the registered casts and tribes depending on local conditions, their population, the economic situation of these strata, and so on. However, the size of these quotas by the decision of the Supreme Court shall not exceed $50 \%$ of the seats.

The state program of the Republic of India has provided support for the representatives of the registered casts and tribes at all levels of school education. First of all government programs are trying to get young people interested in necessity of primary and secondary education. Initially these measures were purely material and the program "Midday breakfast" (translated from English Mid-day Meals Scheme) is one of the most effective measures in this field. For the population where the majority is forced to survive on $\$ 1$ a day, the opportunity to eat at the school for many of them is the only meal a day. Food support program is only the first step on the path of conscious attendance of the educational institution. Thus, according to NGOs, in areas where a large proportion of backward minorities (translated from English "backward minorities") and RC / RT exists, the rate of foundation of elementary schools is low: in India they form one school for 300 people living no further than 1 $\mathrm{km}$; for RC / RT - 200 people; tuition fees at the first stage of primary education (grades 1-5) for students from $\mathrm{RC} / \mathrm{RT}$ is abolished (in some states up to grade 8); free textbooks, uniforms and accessories for the study are provided; in major government programs 1980-90-ies there is a special unit, stipulating privileges to representatives of RC/ RT in this program. From 43 thousands annual scholarship for high school students 13 thousand are reserved for RC/RT. They are also provided with the textbooks on the 15 tribal languages (India Today, 2005). The percentage of literacy of the population is growing, but remains low by the world standards.

Table 1 shows the data on the literacy rate in the history of the census in India.

Table 1. Literacy in India in the 1901-2001

\begin{tabular}{llll}
\hline Census year & \% of literary population \\
\hline & Average & Male & Female \\
1901 & 5,35 & 9,83 & 0,60 \\
1911 & 5,92 & 10,56 & 1,05 \\
1921 & 7,16 & 12,21 & 1,81 \\
1931 & 9,50 & 15,59 & 2,93 \\
1941 & 16,10 & 24,90 & 7,30 \\
1951 & 16,67 & 24,95 & 7,93 \\
1961 & 24,02 & 34,44 & 12,95 \\
1971 & 24,95 & 39,45 & 18,69 \\
1981 & 36,23 & 46,89 & 24,82 \\
1991 & 42,84 & 52,74 & 32,17 \\
2001 & 55,30 & 64,13 & 45,84 \\
\hline
\end{tabular}

In table 1 we are interested in the data of population census after the independence of India in 1951. The table shows a steady increase in the literate population, and particularly high growth rates of female literacy in regard to 1951 , in 2001 the literacy rate of women in the country increased by 5.5 times and men only 2.8 times. At the same time the average literacy at the beginning of the twenty-first century remained relatively low, $55.3 \%$ of the population.

The Government attaches great importance to the elimination of illiteracy in the country and improving the quality of education. Public expenditure on education increased from 3\% of GDP in 1951 to $4 \%$ in 2010 . However, it is recognized that in order to finally solve the problem of primary education in the country it is necessary to raise the level of government spending to $6 \%$ of GDP. The results are shown in Table 2 . 
Table 2. The structure of public expenditure on different types of education, in $\%$

\begin{tabular}{|c|c|c|c|c|c|c|c|c|c|c|}
\hline \multirow[b]{2}{*}{$\begin{array}{c}\text { Type of } \\
\text { education }\end{array}$} & \multicolumn{10}{|c|}{ Five year plan } \\
\hline & $\begin{array}{c}\text { First } \\
1951-56\end{array}$ & $\begin{array}{l}\text { Second } \\
1956-61\end{array}$ & $\begin{array}{c}\text { Third } \\
\text { 1961-66 }\end{array}$ & $\begin{array}{c}\text { Planned } \\
\text { vacations } \\
1966-69 \\
\end{array}$ & $\begin{array}{c}\text { Fourth } \\
1969-74\end{array}$ & $\begin{array}{c}\text { Fifth } \\
1974-79\end{array}$ & $\begin{array}{c}\text { Sixth } \\
1980-85\end{array}$ & $\begin{array}{l}\text { Seventh } \\
1985-90\end{array}$ & $\begin{array}{c}\text { Eighth } \\
1992-97\end{array}$ & $\begin{array}{c}\text { Ninth } \\
1998-2002\end{array}$ \\
\hline $\begin{array}{c}\text { Primary (1 8 } \\
\text { grades) }\end{array}$ & $\begin{array}{c}56 \\
(850)^{*}\end{array}$ & $\begin{array}{c}35 \\
(950)\end{array}$ & $\begin{array}{c}34 \\
(2010)\end{array}$ & $\begin{array}{c}24 \\
(750)\end{array}$ & $\begin{array}{c}30 \\
(2390)\end{array}$ & $\begin{array}{c}35 \\
(3170)\end{array}$ & $\begin{array}{c}33 \\
(8360)\end{array}$ & $\begin{array}{c}37 \\
(28490)\end{array}$ & $\begin{array}{c}47 \\
(92010)\end{array}$ & $\begin{array}{c}58 \\
(118428)\end{array}$ \\
\hline $\begin{array}{c}\text { Secondary } \\
\text { (9-12 grades) }\end{array}$ & $\begin{array}{c}13 \\
(200)\end{array}$ & $\begin{array}{c}19 \\
(510)\end{array}$ & $\begin{array}{c}18 \\
(1030)\end{array}$ & $\begin{array}{c}16 \\
(530)\end{array}$ & $\begin{array}{c}18 \\
(1400)\end{array}$ & $\begin{array}{c}17 \\
(1560)\end{array}$ & $\begin{array}{c}21 \\
(5300)\end{array}$ & $\begin{array}{c}24 \\
(18320)\end{array}$ & $\begin{array}{c}18 \\
(34980)\end{array}$ & $\begin{array}{c}13 \\
(26035)\end{array}$ \\
\hline $\begin{array}{c}\text { Adult } \\
\text { education }\end{array}$ & & & & & & & $\begin{array}{c}9 \\
(2240)\end{array}$ & $\begin{array}{c}6 \\
(4700)\end{array}$ & $\begin{array}{c}9 \\
(18480)\end{array}$ & $\begin{array}{c}3 \\
(6304)\end{array}$ \\
\hline $\begin{array}{c}\text { Higher } \\
\text { education }\end{array}$ & $\begin{array}{c}9 \\
(140)\end{array}$ & $\begin{array}{c}18 \\
(480)\end{array}$ & $\begin{array}{c}15 \\
9870)\end{array}$ & $\begin{array}{c}24 \\
(770)\end{array}$ & $\begin{array}{c}25 \\
(1950)\end{array}$ & $\begin{array}{c}22 \\
(2050)\end{array}$ & $\begin{array}{c}22 \\
(5590)\end{array}$ & $\begin{array}{c}16 \\
(12010)\end{array}$ & $\begin{array}{c}8 \\
(15160)\end{array}$ & $\begin{array}{c}12 \\
(25000)\end{array}$ \\
\hline $\begin{array}{l}\text { technical } \\
\text { education }\end{array}$ & $\begin{array}{c}13 \\
(200)\end{array}$ & $\begin{array}{c}18 \\
(490)\end{array}$ & $\begin{array}{c}21 \\
(1250)\end{array}$ & $\begin{array}{c}25 \\
(810)\end{array}$ & $\begin{array}{c}13 \\
(1060)\end{array}$ & $\begin{array}{c}12 \\
(1070)\end{array}$ & $\begin{array}{c}11 \\
(2730)\end{array}$ & $\begin{array}{c}14 \\
(10830)\end{array}$ & $\begin{array}{c}14 \\
(27860)\end{array}$ & $\begin{array}{c}12 \\
(13735)\end{array}$ \\
\hline $\begin{array}{l}\text { Other types of } \\
\text { education }\end{array}$ & $\begin{array}{c}9 \\
(140)\end{array}$ & $\begin{array}{c}10 \\
(300)\end{array}$ & $\begin{array}{c}12 \\
(730)\end{array}$ & $\begin{array}{c}11 \\
(370)\end{array}$ & $\begin{array}{c}14 \\
(1060)\end{array}$ & $\begin{array}{c}14 \\
(1060)\end{array}$ & $\begin{array}{c}4 \\
(1080)\end{array}$ & $\begin{array}{c}3 \\
(1980)\end{array}$ & $\begin{array}{c}4 \\
(7510)\end{array}$ & $\begin{array}{c}2 \\
(4314)\end{array}$ \\
\hline Total & $\begin{array}{c}100 \\
(1530)\end{array}$ & $\begin{array}{c}100 \\
(2730)\end{array}$ & $\begin{array}{c}100 \\
(5890)\end{array}$ & $\begin{array}{c}100 \\
(3230)\end{array}$ & $\begin{array}{c}100 \\
(7860)\end{array}$ & $\begin{array}{c}100 \\
(9120)\end{array}$ & $\begin{array}{c}100 \\
(25330)\end{array}$ & $\begin{array}{c}100 \\
(76330)\end{array}$ & $\begin{array}{c}100 \\
(196000)\end{array}$ & $\begin{array}{c}100 \\
(203810)\end{array}$ \\
\hline
\end{tabular}

* In brackets allocations in million rupees are indicated

The table shows the growth of public expenditures on education in the country. These figures are even more valuable and interesting, despite the fact that there is a whole layer of private elementary, middle and high schools working on the financial basis. Being not able to pay the poor cannot get there. It should be noted that the Government of the Republic of India financially stimulates funds for the development of the primary and secondary education, compulsory for all citizens of the country, rather than for higher education. In the latter there is a quota system of places for the registered castes.

\section{Discussions}

Foreign historiography (especially English) extensively discusses economic and political events of the 1990-2000s, but the social sphere is poorly analyzed. So a well-known Indian scientist S.S Gill (2002), in his work treats the problem in a new way, considering the economic reforms in India regionally, partially touching upon the problem of public education.

Ongoing debates on education are a cause of scientific conferences, articles and monographs. Since the education system is often analyzed in the context of national food and partly demographic security the work of Bragina E.A. (2002) is worth reading, where great attention is paid to social changes in Indian society in the process of formation of new political institutions. Schematically, but nevertheless amply, the reforms in the joint monograph "India Today" (2005) are highlighted. There is no any definite scientific work with the direct analysis of the primary and secondary education in India, giving a complete picture of what is happening in the field of education there.

\section{Conclusion}

Firstly, there is still no clear understanding among contemporary non-Indian explorers of the modern caste, or more precisely a varna society of India. Since the IV part of the Constitution of India of 1950 (Constitution of India, 2012) makes no distinction between nationals on any grounds. However, in addition to the basic law Registered Castes (RC) have already appeared, for whom there are quotas in educational institutions.

Secondly, the state is trying to break the existing prejudices of Indian citizens who believe that education is a feature of the higher castes. In the best case the primary education is fulfilled by one in five men and one in eight women. In practice, the Indians finish with the ability to read and write, because at the age 8-9 an average Indian becomes a worker and assistant in the family and at home. And at the age 13-14 he himself starts a family of his 
own, even though the fundamental law of the country proclaims that the legal age for marriage is 18 . The state is spending by Indian standards a great public expenditure on a system of primary education and the involvement of a larger number of students and teachers in the learning process, and there are some positive results, which is not enough for the status of a world state.

\section{Recommendations}

The article can be used for further study of the problems of primary and secondary education among teachers and historians. The results of this study can be used in the research and teaching on the comparative analysis of systems of primary and secondary education in the works based on modern social history of India, in training courses on national and food security in South Asia, as well as the issues related to social and gender inequality.

\section{Acknowledgments}

The work is performed according to the Russian Government Program of Competitive Growth of Kazan Federal University

\section{References}

Bragina, E. A. (2002). Vremya i bremya reform. Svobodnaya mysl' - XXI, 5, 32-38.

Constitution of India (Updated up to (Ninety-Eighth Amendment) Act, 2012). (2012). http://lawmin.nic.in/olwing/coi/coi-english/coi-indexenglish.htm

Doklad o chelovecheskom razvitii. (2011). Ustoichivoe razvitie i ravenstvo vozmozhnostei: luchshee budushhee dlya vseh. Moskwa: Ves' mir.

Empowering Education: the Mahila Samakhya experience. (2012). http://mahilasamakhyakarnataka.org/

Gupta, R. K., \& Sarkar, S. C. (1982). Overview of Constitutional Law of India. Delhi. pp. 147-158.

India segodnya. (2005). Moskwa: Institut vostokovedenya RAN.

India. A Reference Annual. (1994). New Delhi: Publication Division. pp. 13-20.

India: strana I eyo ee region. (2000). Moskwa: E'ditorial.

Jill, S. S. (2002). Economika razvivayushhegosya regiona: opyt Indii. Problemy prognozirovaniya. Institut Narodnohozyaistvennogo prognozirovaniya RAN., 6, 65-74.

Kruglova, E. V. (2008). Tradicionnyi sotsio-kulturnyi komplex kak faktor uspeshnogo vhozhdeniya v global'nyi miroporyadok na primere Indii. Vzaimodeisrvie mirovyh civilizacyi. Istoriya i sovremennost'. Moskwa: RUDN. (209-231)

Malyarov, O. V. (2006). Budzhetnyi process i budzhetnaya politika gosudarstva v Indii. Moskwa: Institut vostokovedenya RAN.

Malyarov, O. V. (2010). Nezavisimaya India. E'volutcia sotsial'no-e'konomicheskoi modeli i razvitie e'konomiki. Moskwa: Institut vostokovedenya RAN.

Religiya i sekulyarism na Vostoke. (1993). Moskwa: Nauka.

Sarva Shiksha Abhiyan. (2010). http://www.slideshare.net/jannap/sarva-shiksha-abhiyan

Sauvant, K., \& Pradhan, P. (2009). The Rise of Indian Multinationals. New York: Palgrave.

Suprunova, L. L. (2009). Opyt modernizacii obrazovaniya v Indii. Moskwa: Progress-Tradicia.

The Constitution of India (As on the lsl February, 1990). (1990). Delhi.

Volodin, A. G., \& Shirokov, G. K. (2002). Globalizatsia: nachalo, tendentsii, perspektivy. Moskwa: Institut vostokovedenya RAN.

\section{Copyrights}

Copyright for this article is retained by the author(s), with first publication rights granted to the journal.

This is an open-access article distributed under the terms and conditions of the Creative Commons Attribution license (http://creativecommons.org/licenses/by/3.0/). 